образования» [Электронный ресурс]. - Режим доступа: http://www.rg.ru/2013/11/25doshkstandart-dok.html.

2. Ишмакова М.С. Конструирование в дошкольном образовании в условиях введения ФГОС: пособие для педагогов. - М.: ИПЦ «Маска», 2013. - 100 с.

3. ПервоРобот LEGO WeDo. Книга для учителя [Электронный ресурс]. - The LEGO Group, 2009. - 53 c.

4. Пробная версия учебных материалов WeDo 2.0 [Электронный ресурс]. - The LEGO Group, 2016. - 45 c.

5. Фартышев Д.А. Образовательная робототехника на платформе HUNA-MRT [Электронный ресурс]. - Иркутск, 2016. - 24 с.

6. ROBOKIDS Manual (English Ver.) - Seoul: RoboRobo, 2009 - 11 p.

7. Дмитриева A.M., Максимов В.В. Образовательный конструктор RoboRobo RoboKids на занятиях по робототехнике для учащихся начальных классов. - В сб. «Методика преподавания основ робототехники школьникам в основном и дополнительном образовании: Материалы II Всероссийской научно-методической конференции». - Екатеринбург: УрГПУ, 2014. - С. 22.

\title{
Геологическое воспитание учащихся в городской классической гимназии города Якутска
}

Черепанова А.М., инженер-исследователь, Институт мерзлотоведения им. П.И. Мельникова СО РАН,

Научный руководитель: к.2.н., в.н.с. Спектор В.В.

Изучение геологических дисциплин является основой фундаментального образования, знание основ геологии - один из показателей образованности человека. Геологические знания наряду с другими науками позволяют получить представления о строении Земли, геологических процессах и предсказать будущее географической обстановки.

В 2014 году в городской классической гимназии города Якутска под руководством учителя географии Неустроевой Анны Ивановны, сотрудников Института мерзлотоведения им. П.И. Мельникова: к.г.н. Спектора Валентина Владимировича и инженера-исследователя Черепановой Александры Михайловны открылось научное общество учащихся «Геокриолог». Целью данного общества выступило формирование у детей глубоких знаний и умений в проведении самостоятельной исследовательской деятельности.

Геология - фундаментальная наука, а точнее, целое семейство родственных наук:, таких как тектоника, минералогия, петрография, палеонтология, геофизика, геохимия и, конечно же, геокриология. Базовые геологические знания в школе приобретаются на уроках географии и естествознания. Как показывает практика, недостаток отведенного времени изучению природных процессов сказывается на общей эрудиции населения в понимании условий освоения и проживания в северных регионах, где вечная мерзлота определяет всю жизнедеятельность. Поэтому из всех 
геологических дисциплин нами было решено основное внимание уделить курсу «Геокриология» и проводить внеклассные занятия для учащихся с 5 по 9 классы.

Помимо лекционной части, важным элементом в работе внеклассных занятий является познавательные экскурсии и экспедиции, которые строятся на изучении, накоплении и использовании полевого материала. При проведении экспедиций и экскурсий необходимо исходить из требований календарного плана. Необходимо учитывать время проведения экскурсии, так как этим определяется подготовленность учащихся к самостоятельной работе при выполнении практических заданий, сбора полевого материала для тем курса, подлежащих дальнейшему изучению.

За три года работы научного общества «Геокриолог» было проведено несколько экскурсий на природные объекты (Табагинский мыс, источник Булуус)», где учащиеся воочию ознакомились с криогенными процессами и явлениями, посетили природную наледь Булуус и узнали много нового о пользе и свойствах подземных вод. Также на научно-исследовательском стационаре Института мерзлотоведения «Туймаада» ребята с помощью металлического щупа и мерзлотомера научились определять мощность протаивания грунта (Рис.1), ознакомились с принципами работы оборудований, установленных на стационаре. Совместно с сотрудниками Института мерзлотоведения выезжали на замеры мощности снежного покрова. Посещение подземной лаборатории Института мерзлотоведения никого не оставило равнодушным, ребята своими глазами увидели мерзлые грунты , в народе так называемую «вечную мерзлоту».

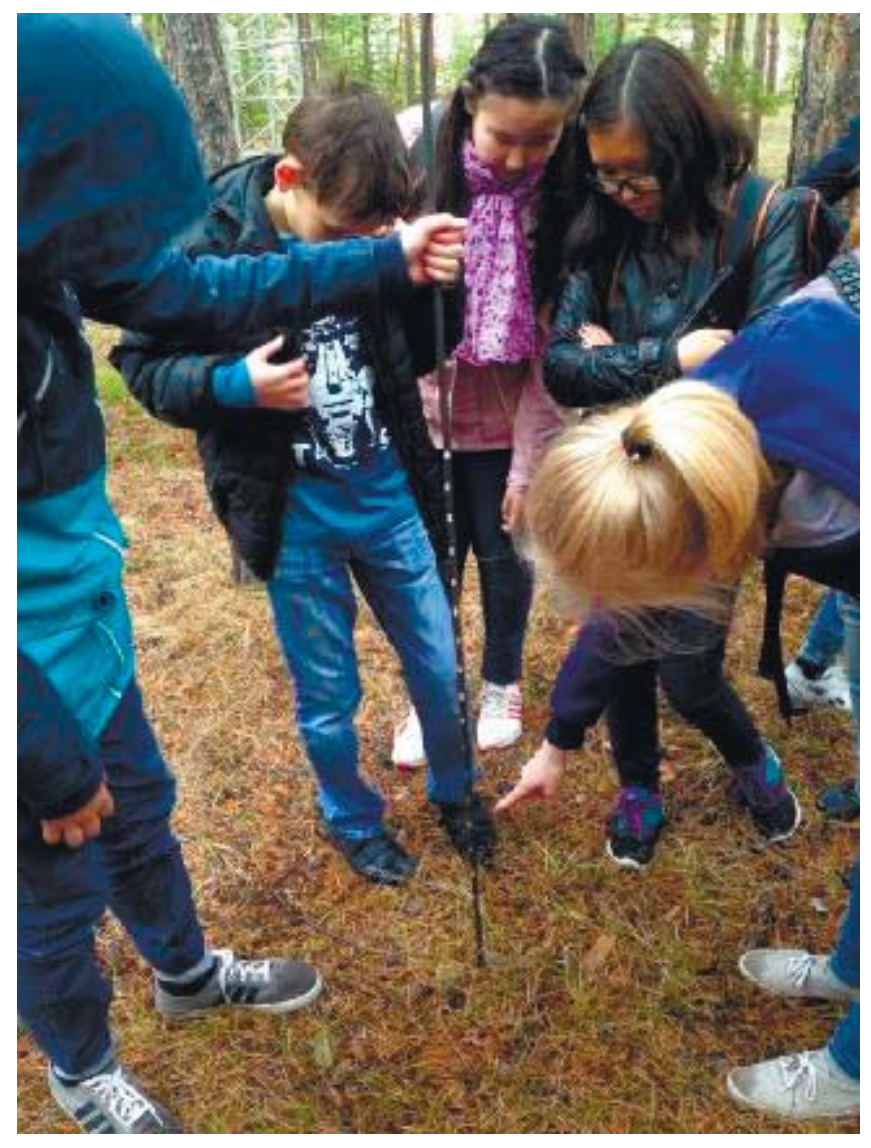

Рис. 1. Измерение мощности протаивания грунта металлическим щупом Фото А.М. Черепановой 
Для самостоятельной научно-исследовательской работы учащимся было предложено изучить и оценить проявления криогенных процессов в виде морозобойных растрескиваний. Объектом изучения были выбраны асфальтированные участки на территории историко - архитектурного комплекса «Старый город» (Рис.2).

Учащиеся создали методику по изучению трещин, выявили проблему, происходящую вследствие активизации криогенных процессов; ознакомились о возможных последствиях криогенных процессов на территории г. Якутска, обозначили необходимость проведения мероприятий по защите от негативных последствий криогенных процессов.

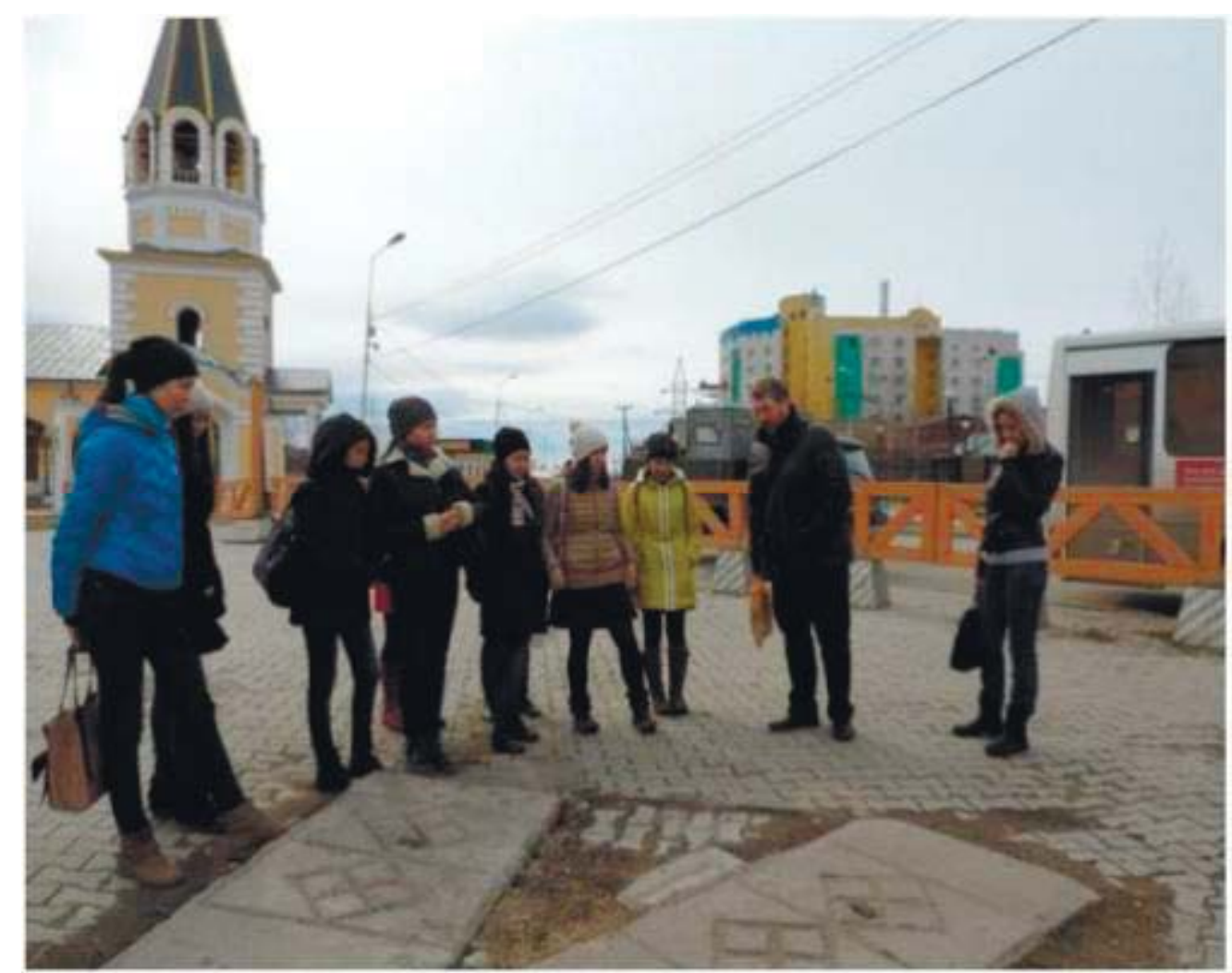

Рис. 2. Выбор участка для самостоятельной исследовательской работы Фото А.М. Черепановой

С результатами работ учащиеся ежегодно выступают на научно-практической конференции «Шаг в будущее» (Рис.3), научно-образовательной экологической конференции «Кулаковские чтения». Их доклад на тему «Интенсивность морозобойных растрескиваний на тротуарах города Якутска» был опубликован в материалах IX Международной конференции и летней школы, организованной РГПУ им. Герцена (г. Санкт-Петербург, 30 июня-9 июля, 2015 г.). 


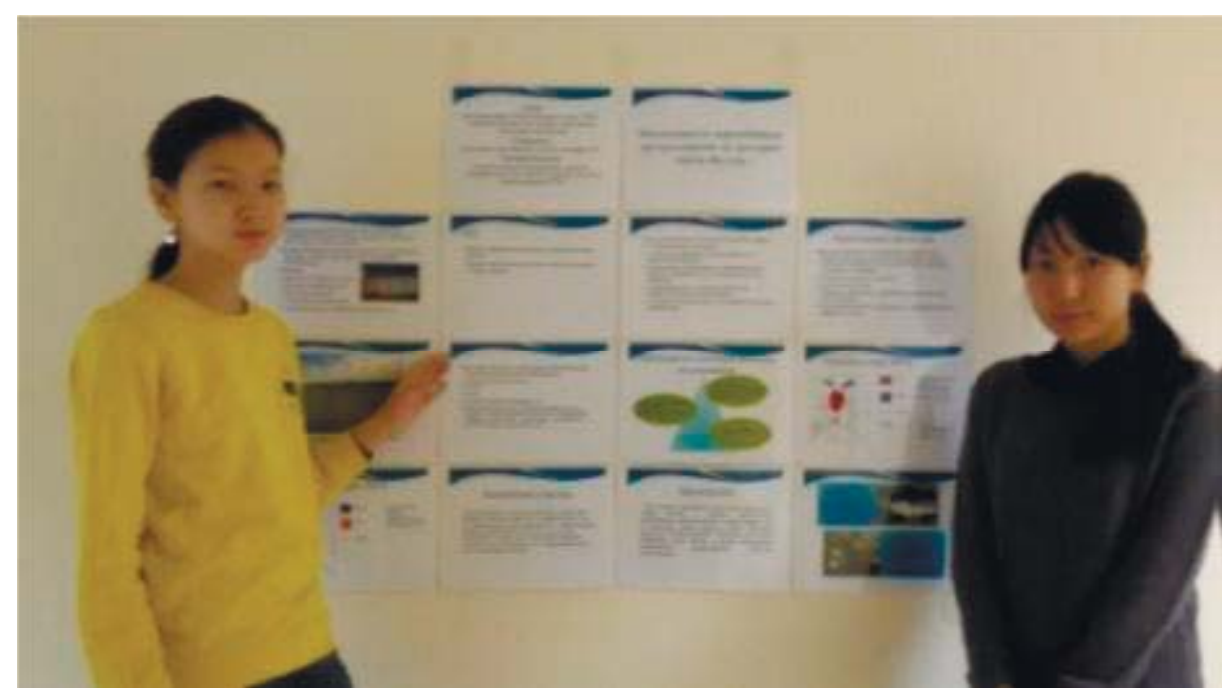

Рис. 3. Учащиеся 9 класса городской классической гимназии на конференции «Кулаковские чтения». Фото А.И. Неустроевой

Учащиеся, посещающие внеклассные занятия по геокриологии, несомненно, расширили свой кругозор, приобрели знания о родном крае, научились основам самостоятельной исследовательской деятельности.

Деятельность научного общества учащихся «Геокриолог» способствует представлению у учащихся о взаимосвязанности и взаимозависимости природных процессов и о необходимости ответственного отношения человека к созданию любых проектов, связанных с нарушением природной среды вообще и геокриологической в частности. Геокриологическая подготовка на уровне общеобразовательной школы представляет дополнительные возможности для профессионального самоопределения школьников.

\section{Список литературы:}

1. Гаврилова М.К. Климаты холодных регионов Земли: Учебное пособие. Якутск: Изд-во СО РАН, 1998. - 206 с.

2. Гаврилова М.К. Климат Центральной Якутии. Изд. 2-е. - Якутск: Кн. Изд-во, 1973. $-120 \mathrm{c}$.

\section{Особенности формирования социального интеллекта младших школьников}

Шевченко К.В., студент, Технический институт (филиал) Северо-Восточного федерального университета, 2. Нерюнгри

\section{E-mail: 25lena68vitia@mail.ru}

Научный руководитель: старший преподаватель Николаева И.И.

В настоящее время интерес к изучению социального интеллекта привлекает все большее внимание ученых в области практической и научной психологии. Актуальность данного исследования заключается в том, что, в последнее время, очень часто возникают трудности в умении налаживать контакт друг с другом, умение контролировать свое 